\title{
Estrogen receptor $\beta$ suppresses inflammation and the progression of prostate cancer
}

\author{
LONG XIAO, YAOHUI LUO, RONGFEN TAI and NINGNAN ZHANG \\ Department of Urology, The First People's Hospital of Yunnan Province, \\ Kunming University of Science and Technology, Kunming, Yunnan 650041, P.R. China
}

Received June 5, 2018; Accepted January 11, 2019

DOI: $10.3892 / \mathrm{mmr} .2019 .10014$

\begin{abstract}
Previous studies demonstrated that estrogen receptor $\beta(E R \beta)$ signaling alleviates systemic inflammation in animal models, and suggested that ER $\beta$-selective agonists may deactivate microglia and suppress $\mathrm{T}$ cell activity via downregulation of nuclear factor $\kappa$-light-chain-enhancer of activated $B$ cells $(N F-\kappa B)$. In the present study, the role of $\mathrm{ER} \beta$ in lipopolysaccharide (LPS)-induced inflammation and association with $\mathrm{NF}-\kappa \mathrm{B}$ activity were investigated in PC-3 and DU145 prostate cancer cell lines. Cells were treated with LPS to induce inflammation, and ELISA was performed to determine the expression levels of inflammatory cytokines, including tumor necrosis factor- $\alpha$ (TNF- $\alpha)$, monocyte chemoattractant protein 1 (MCP-1), interleukin (IL)-1 $\beta$ and IL-6. MTT and Transwell assays, and Annexin V/propidium iodide staining were conducted to measure cell viability, apoptosis and migration, respectively. Protein expression was determined via western blot analysis. LPS-induced inflammation resulted in elevated expression levels of TNF- $\alpha$, IL-1 $\beta$, MCP-1 and IL- 6 compared with controls. ER $\beta$ overexpression significantly inhibited the LPS-induced production of TNF- $\alpha$, IL-1 $\beta$, MCP-1 and IL-6. In addition, the results indicated that ER $\beta$ suppressed viability and migration, and induced apoptosis in prostate cancer cells, which was further demonstrated by altered expression of proliferating cell nuclear antigen, B-cell lymphoma 2-associated X protein, caspase-3, E-cadherin and matrix metalloproteinase-2. These effects were reversed by treatment with the ER $\beta$ antagonist PHTPP or ER $\beta$-specific short interfering RNA. ER $\beta$ overexpression reduced the expression levels of p65 and phosphorylated $\mathrm{NF}-\kappa \mathrm{B}$ inhibitor $\alpha(\mathrm{I} \kappa \mathrm{B} \alpha)$, but not total $\mathrm{I} \kappa \mathrm{B} \alpha$ expression in
\end{abstract}

Correspondence to: Dr Ningnan Zhang, Department of Urology, The First People's Hospital of Yunnan Province, Kunming University of Science and Technology, 157 Jinbi Road, Kunming, Yunnan 650041, P.R. China

E-mail: xiaoxuwangchao@163.com

Key words: prostate cancer, estrogen receptor $\beta$, nuclear factor $\kappa$-light-chain-enhancer of activated B cells signaling pathway, lipopolysaccharide
LPS-treated cells. In conclusion, ER $\beta$ suppressed the viability and migration of the PC-3 and DU145 prostate cancer cell lines and induced apoptosis. Furthermore, it reduced inflammation and suppressed the activation of the $\mathrm{NF}-\kappa \mathrm{B}$ pathway, suggesting that ER $\beta$ may serve roles as an anti-inflammatory and anticancer agent in prostate cancer.

\section{Introduction}

Chronic inflammation is the leading cause of epithelial malignancies, such as prostate cancer (1). The progression of high-grade prostate cancer is associated with chronic intraprostatic inflammation (2). Previous studies reported a key role for inflammatory responses in the pathogenesis of prostate cancer $(3,4)$. The molecular effects of inflammation on carcinogenesis include the regulation of the tumor microenvironment induced by altered levels of inflammatory cytokines, reactive oxygen species and transcriptional factors (5). Therefore, improved understanding of chronic inflammation and its underlying mechanisms may aid the development of therapeutic strategies in reducing prostate cancer-associated mortality.

The adaptive immune system regulates antitumor effects via immunosurveillance (6); however, certain tumors, such as gastrointestinal cancer, are able to manipulate inflammatory signals to their own advantage (7). In this context, nuclear factor $\kappa$-light-chain-enhancer of activated $B$ cells $(\mathrm{NF}-\kappa \mathrm{B})$, a master transcription factor, has been reported as the main mediator of proinflammatory processes in the pathogenesis of prostate cancer (8). During the progression of prostate cancer, $\mathrm{NF}-\kappa \mathrm{B}$ promotes tumor invasion, metastasis, cell survival and chemoresistance (9). Constitutive activation of $\mathrm{NF}-\kappa \mathrm{B}$ has been demonstrated in primary prostate cancer, and is associated with castration-resistant phenotypes and the loss of androgen receptor function (10). Therefore, suppression of the $\mathrm{NF}-\kappa \mathrm{B}$ pathway may regulate chronic inflammatory responses and reduce their oncogenic effects (11).

Estrogen receptor $\beta$ (ER $\beta$ ) was reported to be expressed in prostate carcinoma cells; ER $\beta$-regulated estrogen signaling served to inhibit tumor progression in patients with prostate cancer (12). Furthermore, it was demonstrated that ER $\beta$-selective agonists are able to deactivate microglia and suppress $\mathrm{T}$ cell activity via downregulation of $\mathrm{NF}-\kappa \mathrm{B}(13)$. In addition, it was reported that $\mathrm{ER} \beta$ precludes $\mathrm{NF}-\kappa \mathrm{B}$ activation; 
the loss of ER $\beta$ may be associated with chronic inflammation in prostate cancer (14). Collectively, these findings indicate that $\mathrm{ER} \beta$ may reversibly regulate prostate inflammation via suppression of the NF- $\kappa \mathrm{B}$ signaling pathway. Thus, in the present study, the mechanisms underlying the therapeutic roles of ER $\beta$ in prostate inflammation and regulation of the $N F-\kappa B$ signaling pathway were investigated.

\section{Materials and methods}

Cell culture. PC-3 and DU145, human prostate cancer cell lines, were obtained from the Chinese Academy of Sciences (Shanghai, China). PC-3 and DU145 prostate cancer cells were cultured in RPMI-1640 culture medium (BD Biosciences, San Jose, CA, USA) with $10 \%$ fetal bovine serum (FBS; Gibco; Thermo Fisher Scientific, Inc., Waltham, MA, USA), $100 \mu \mathrm{g} / \mathrm{ml}$ streptomycin (Sigma-Aldrich; Merck KGaA, Darmstadt, Germany) and $100 \mathrm{U} / \mathrm{ml}$ penicillin (Sigma-Aldrich; Merck KGaA). The cell lines were maintained in humidified incubators with $5 \% \mathrm{CO}_{2}$ at $37^{\circ} \mathrm{C}$. PC-3 and DU145 cells were transfected with an ER $\beta$ expression plasmid and empty vector was used as negative control using Lipofectamine ${ }^{\circledR} 2000$ (Invitrogen; Thermo Fisher Scientific, Inc.). Construction of receptor expression vectors was made as previously described (15). Briefly, to construct the human ER $\beta$ expression plasmid, ER $\beta /$ pcDNA3.1+Zero pcDNA3.1+Zero/ER $\beta$, A 2367 bp fragment including the human ER $\beta$ sequence was excised from the ER $\beta /$ pcDNA3 plasmid (originally isolated from the ER $\beta /$ Pcmv5 plasmid) and inserted into the HindIII/Xbal sites in the vector pCDNA3.1+Zero (Invitrogen; Thermo Fisher Scientific, Inc.). Then, $10 \mathrm{ng} / \mathrm{ml}$ of lipopolysaccharide (LPS; Sigma-Aldrich; Merck KGaA) or dimethyl sulfoxide (DMSO; Santa Cruz Biotechnology, Inc., Dallas, TX, USA) and PHTPP (a selective ER $\beta$ receptor inhibitor, Tocris Bioscience, Bristol, $\mathrm{UK}$ ) was added to cell cultures and incubated for $24 \mathrm{~h}$ with $5 \% \mathrm{CO}_{2}$ at $37^{\circ} \mathrm{C}$. The time between transfection and treatment with LPS/DMSO was $12 \mathrm{~h}$.

ER $\beta$-specific short interfering RNA (siRNA) transfection. The sequences of the siRNAs targeting ER $\beta$ and scramble RNA were as follows: siRNA-ER $\beta \# 1,5$-GCCCUGCUGUGAUGA AUUAdTdT-3'; siRNA-ER $\beta \# 2$, 5'-CCACCUUCCUUUCUA UUAUdTdT-3'; siRNA-ER $\beta \# 3$, 5'-CGGGCUUCAUAAGCU AGAUdTdT-3'; and scramble, 5'-GAACUGAUGACAGGG AGGCTT-3'. Cells (5x104/well) were seeded in 96-well plates. Since the expression level of ER $\beta$ was most pronounced with siRNA-ER $\beta \# 1$, this cell line was selected for the following experiments. DU145 cells were transfected with siRNA (150 pmol $/ \mathrm{ml}$ ) using Lipofectamine $2000^{\circledR}$ at $37^{\circ} \mathrm{C}$ overnight. Prior to transfection, the culture medium was replaced with Opti-MEM ${ }^{\circledR}$ Reduced Serum Medium (Gibco; Thermo Fisher Scientific, Inc.). The resulting cell populations were selected for further experiments. The levels of ER $\beta$ mRNA and protein expression were analyzed via reverse transcription-quantitative polymerase chain reaction (RT-qPCR) and western blotting, respectively.

$R T$ - $q P C R$. Total RNA was extracted from cells using TRIzol ${ }^{\circledR}$ (Invitrogen; Thermo Fisher Scientific, Inc.). RNA purity and concentration were determined using a NanoDrop ${ }^{\mathrm{TM}} 2000$ spectrophotometer (NanoDrop Technologies; Thermo Fisher Scientific, Inc., Wilmington, DE, USA). Total RNA was reverse transcribed into cDNA using a PrimeScript Master Mix kit (Takara Bio, Inc., Otsu, Japan) according to the manufacturer's protocols. The cDNA was amplified with SYBR Green Master Mix (Takara Bio, Inc.), which was performed using a LightCycler ${ }^{\circledR} 96$ system (Roche Applied Science, Penzberg, Germany). The primers $\left(5^{\prime} \rightarrow 3^{\prime}\right)$ used in qPCR were: $G A P D H$, forward CGACCACTTTGTCAAGCT CA, reverse AGGGGAGATTCAGTGTGGTG; $E R \beta$, forward CAAGCTCATCTTTGCTCCAGA, reverse GCCTTGACA CAGAGATATTCTTTG. The thermocycling program was: $50^{\circ} \mathrm{C}$ for $2 \mathrm{~min}, 95^{\circ} \mathrm{C}$ for $2 \mathrm{~min}$, followed by 40 cycles of $95^{\circ} \mathrm{C}$ for $15 \mathrm{sec}$ and $60^{\circ} \mathrm{C}$ for $30 \mathrm{sec}$. At the end of each PCR run, a melting curve analysis from 65 to $95^{\circ} \mathrm{C}$ was applied to all reactions to ensure the specificity of the amplified product. GAPDH was used as a reference gene, and the qPCR data was analyzed using LightCycler 96 Application Software version 1.1 (Roche Applied Science). The $2^{-\Delta \Delta \mathrm{Cq}}$ method (16) was employed to determine the relative expression of the target gene.

Cell viability assay. Cells cultured in RPMI-1640 medium were seeded into 96 -well plates at a density of $5 \times 10^{3}$ cells/well and incubated at $37^{\circ} \mathrm{C}$ for $24 \mathrm{~h}$. PC-3 and DU145 parental cells (negative vector transfected cells used as the control), and ER $\beta$ plasmid-transfected cells were treated with LPS for 24, 48, 72 and $96 \mathrm{~h}$. MTT assay solution $(20 \mu \mathrm{l})$ was applied to the medium, which was subsequently incubated for $4 \mathrm{~h}$ at $37^{\circ} \mathrm{C}$. Then, $150 \mu 1$ DMSO was added to cells for $10 \mathrm{~min}$ to solubilize the formazan crystals. Vehicle $(0.1 \%$ DMSO) was used as the control. The optical density values in each well were measured at $595 \mathrm{~nm}$ with an absorption spectrophotometer (Olympus Corporation, Tokyo, Japan). All treatments were performed in triplicate.

Transwell migration assay. Cells $\left(5 \times 10^{4}\right.$ cells/well) were cultured in serum-free RPMI-1640 medium (500 $\mu \mathrm{l})$ and plated in the upper chambers of Transwell plates. RPMI-1640 with 15\% FBS (600 ml; Beijing Transgen Biotech Co., Ltd., Beijing, China) was plated in the lower chambers. Plates were incubated in humidified conditions with $5 \% \mathrm{CO}_{2}$ for $24 \mathrm{~h}$ at $37^{\circ} \mathrm{C}$. Then, the inserts were washed with PBS three times, and cells on the upper surface were removed with a cotton swab. The cells remaining on the bottom surface of the inserts were treated with methanol $(500 \mu \mathrm{l}, 50 \mu \mathrm{g} / \mathrm{ml})$ at $4^{\circ} \mathrm{C}$ for $10 \mathrm{~min}$ prior to staining with hematoxylin at room temperature for $10 \mathrm{~min}$. A total of five predetermined fields (magnification, $\mathrm{x} 200$ ) of each well were selected for cell counting. Images were captured by a photomicroscope (Axiovert $200 \mathrm{M}$; Carl Zeiss AG, Oberkochen, Germany).

Western blotting. Following rinsing in cold PBS, total protein was extracted from the cells using lysis buffer (0.1\% SDS, $50 \mathrm{mmol}$ Tris-base, 1\% Triton X-100, $150 \mathrm{mmol}$ sodium chloride, $1 \mathrm{mmol}$ sodium orthovanadate, $0.5 \%$ sodium deoxycholate, $1 \%$ protease inhibitor cocktail and $10 \mathrm{mmol}$ sodium fluoride) and quantified using the Bradford protein assay. Proteins $(20 \mu \mathrm{g})$ were separated via $10 \%$ SDS-PAGE at $100 \mathrm{~V}$ and electrotransferred onto $0.45 \mu \mathrm{m}$ polyvinylidene 
difluoride membranes. The membranes were blocked with $5 \%$ non-fat milk in TBS-Tween $20(10 \%)$ at room temperature for $2 \mathrm{~h}$, and then incubated with primary antibodies against $\operatorname{ER} \beta$ (1:500; cat. no. ab3576), p65 (1:100; cat. no. ab16502), $\mathrm{NF}-\kappa \mathrm{B}$ inhibitor $\alpha(\mathrm{I} \kappa \mathrm{B} \alpha, 1: 200$; cat. no. ab32518), phosphorylated (p)-IкB $\alpha$ (1:200; cat. no. ab133462), proliferating cell nuclear antigen (PCNA; 1:50; cat. no. ab92552), E-cadherin (1:100; cat. no. ab40772), B-cell lymphoma 2-associated $\mathrm{X}$ protein (Bax; 1:200; cat. no. 32503), caspase-3 (1:200; cat. no. ab32351), matrix metalloproteinase-2 (MMP-2; 1:200; cat. no. ab37150) and $\beta$-actin (1:50; cat. no. ab8226; Abcam, Cambridge, UK) overnight at $4^{\circ} \mathrm{C}$. Anti-rabbit HRP-conjugated secondary antibody (Thermo Fisher Scientific, Inc.) was then added at room temperature for $1 \mathrm{~h}$, and membranes were incubated for $20 \mathrm{~min}$. Protein bands were visualized using an enhanced chemiluminescence kit (Pierce; Thermo Fisher Scientific, Inc.). Protein expression was quantified using Total Lab Nonlinear Dynamic Image (version 2009) analysis software (MathWorks, Natick, MA, USA).

ELISA. High binding microtiter plates were coated overnight at $4^{\circ} \mathrm{C}$ with $100 \mu \mathrm{l}$ per well of III-BSA coating antigen $(0.05 \mu \mathrm{g} / \mathrm{ml}$ in coating buffer). Cells were then rinsed with PBS and blocked with $3 \%$ bovine serum albumin (BSA; Beijing Transgen Biotech Co., Ltd.) in PBS for $1 \mathrm{~h}$ at room temperature. Anti-tumor necrosis factor- $\alpha$ (TNF- $\alpha$; cat. no. ab91235), anti-interleukin (IL)-1 $\beta$ (cat. no. ab242234), anti-monocyte chemoattractant protein-1 (MCP-1; cat. no. ab9669) and anti-IL-6 (cat. no. ab178013) monoclonal antibodies were purchased from Abcam, and were diluted in PBS $+3 \%$ BSA, added to cells and incubated at room temperature for $2 \mathrm{~h}$. Following washing with PBS, cells were incubated with goat anti-mouse secondary antibodies (1:100; cat. no. BMS2007INST; Thermo Fisher Scientific, Inc.), and incubated for $60 \mathrm{~min}$ at room temperature. Cells expressing TNF- $\alpha$, IL-1 $\beta$, MCP-1 and IL- 6 were detected using an ELISA Kit according to the manufacturer's protocols; protein concentrations were determined using a Spectramax M5 plate reader (Molecular Devices, LLC, Sunnyvale, CA, USA).

Annexin V/propidium iodide (PI) assay. Apoptotic cell death was determined using the Annexin V (conjugated to Alexa Fluor 594; excitation/emission: 590/617 nm) Apoptosis Detection Kit (BioVision, Inc., Milpitas, CA, USA) and PI. Following transfection, cells were incubated for $48 \mathrm{~h}$, and then collected and stained with Annexin V/PI according to the manufacturer's protocols. The percentage of early apoptotic, late apoptotic and necrotic cells were determined using a flow cytometer (BD Bioscience) and analyzed with guavaSoft 3.1.1 software (EMD Millipore, Billerica, MA, USA). The occurrence of apoptosis in each group was investigated in $\geq 3$ independent experiments.

Statistical analysis. SPSS 19.0 (IBM Corp., Armonk, NY, USA) was used for all statistical analyses. Data are presented as the mean \pm standard deviation. Comparisons across three or more groups were performed using one-way analyses of variance followed by Tukey's test, while a Student's t-test was used to determine significant differences between two groups. $\mathrm{P}<0.05$ was considered to indicate a statistically significant difference. All tests were investigated in $\geq 3$ independent experiments.

\section{Results}

Elevated expression of proinflammatory genes in prostate cancer cells following LPS treatment. Following incubation with LPS for $24 \mathrm{~h}$, the expression levels of proinflammatory cytokines in the supernatants of the prostate cancer cell lines PC-3 and DU145 were determined using ELISA. Stimulation with LPS led to significantly elevated expression levels of TNF- $\alpha$, MCP-1, IL-1 $\beta$ and IL-6 in PC-3 and DU145 cells compared with controls treated with DMSO ( $<<0.05$; Fig. 1A). These results indicated that LPS successfully induced inflammation in prostate cancer cells.

To investigate whether $\mathrm{p} 65$ is regulated by ER $\beta$ signaling, the expression levels of proteins involved in the NF- $\kappa \mathrm{B}$ pathway were determined. As presented in Fig. 1B, increased p65 and $\mathrm{p}-\mathrm{I} \kappa \mathrm{B} \alpha$ expression, and decreased $\mathrm{ER} \beta$ expression were observed in LPS-stimulated PC-3 and DU145 cells compared with the controls; however, no significant differences were reported for total I $\mathrm{B} \alpha \alpha$ expression.

$E R \beta$ reduces the $L P S$-induced release of inflammatory cytokines via suppression of the $N F-\kappa B$ pathway in vitro. To investigate the role of the $\mathrm{NF}-\kappa \mathrm{B}$ pathway in the regulation of ER $\beta$-induced inflammation, western blot analysis was performed to determine the expression of $\mathrm{NF}-\kappa \mathrm{B}$ pathway-associated proteins in PC-3 and DU145 cells transfected with an $\mathrm{ER} \beta$ expression vector or treated with the ER $\beta$ antagonist PHTPP. It was revealed that ER $\beta$ overexpression suppressed the expression of p65 and p-I $\kappa \mathrm{B} \alpha$, but not total I $\mathrm{B} \mathrm{B} \alpha$ expression in LPS-stimulated PC-3 and DU145 cells compared with control cells. This expression profile was reversed following treatment with PHTPP (Fig. 2A).

Providing ER $\beta$ is a suppressor of prostate inflammation, ER $\beta$ activation may suppress the expression of certain proinflammatory genes. To investigate the involvement of ER $\beta$ signaling in LPS-induced inflammation, the expression of the proinflammatory cytokines TNF- $\alpha$, IL-1 $\beta$, MCP-1 and IL-6, was determined in cells overexpressing ER $\beta$ and transfected cells treated with PHTPP via ELISA. The results demonstrated that the LPS-induced production of TNF- $\alpha$, MCP-1, IL-1 $\beta$ and IL-6 was significantly reduced in prostate cancer cells following overexpression of ER $\beta$ compared with negative control vector cells $(\mathrm{P}<0.05$; Fig. $2 \mathrm{~B})$. This expression profile was significantly reversed in PHTPP-treated transfected cells compared with ER $\beta$-overexpressing cells $(\mathrm{P}<0.05)$. These data suggested that ER $\beta$ signaling regulated LPS-induced prostate cancer cell inflammation.

ER $\beta$ activation suppresses viability and migration, and promotes the apoptosisofprostate cancercells. Todetermine the effects of ER $\beta$ overexpression on prostate cancer cell viability, apoptosis and migration, MTT, Annexin V/PI and Transwell assays were performed using control, ER $\beta$-overexpressing, and ER $\beta$-inhibited cells. As presented in Fig. 3A, ER $\beta$ overexpression significantly suppressed the viability of PC-3 

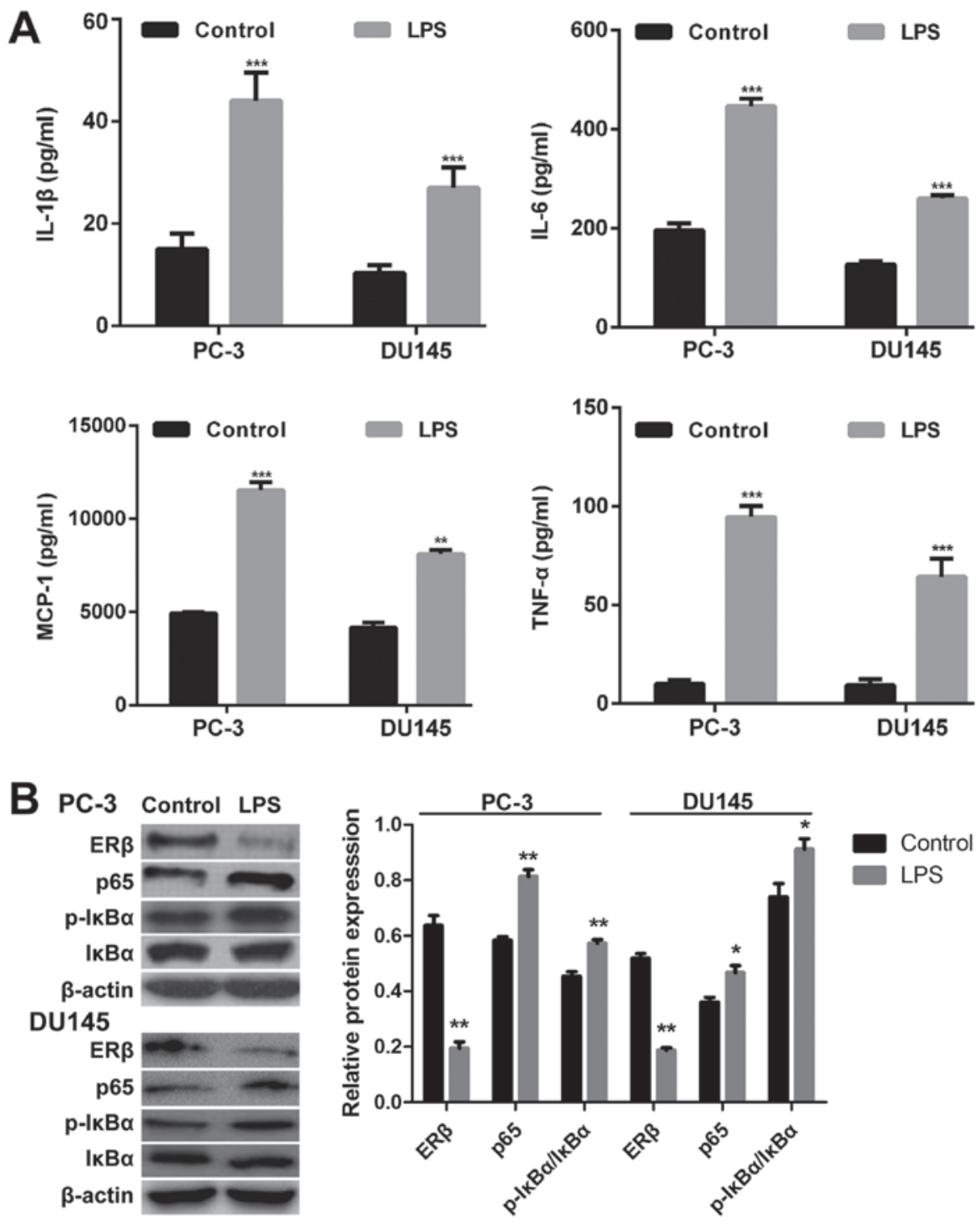

Figure 1. Elevated expression of proinflammatory genes and activation of the NF- $\mathrm{kB}$ pathway in prostate cancer cells following LPS treatment. (A) Expression of proinflammatory cytokines was determined using ELISA in LPS-treated and control PC-3 and DU145 prostate cancer cells. (B) Expression of NF- $\mathrm{kB}$ pathway-associated proteins was determined via western blot analysis in LPS- and control-treated PC-3 and DU145 cells. Data are presented as the mean \pm standard deviation; ${ }^{*} \mathrm{P}<0.05,{ }^{* *} \mathrm{P}<0.01$ and ${ }^{* * *} \mathrm{P}<0.001$ vs. the control group. Control, treatment with dimethyl sulfoxide; ER $\beta$, estrogen receptor $\beta$; IL, interleukin;

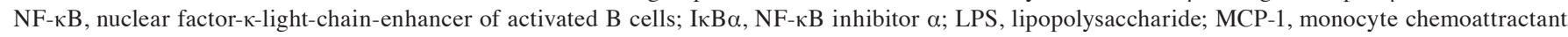
protein 1 ; p, phosphorylated; TNF- $\alpha$, tumor necrosis factor $\alpha$.

and DU145 cells compared with control and PHTPP-treated transfected cells $(\mathrm{P}<0.01)$. When cells were treated with PHTPP, their viability was markedly reduced compared with ER $\beta$-overexpressed cells. Furthermore, the number of apoptotic cells among those treated with ER $\beta$ transfection was significantly higher compared with control and ER $\beta$-inhibited cells $(\mathrm{P}<0.01$; Fig. 3B). The cell migration assay revealed that upregulation of ER $\beta$ significantly decreased migration compared with control and PHTPP-treated transfected PC-3 and DU145 cells $(\mathrm{P}<0.01$; Fig. 4A).

As ER $\beta$ signaling appeared to be involved in the regulation of cell viability, apoptosis and migration, and the expression of proteins associated with these properties was determined. PCNA, Bax and caspase-3, and MMP-2 and E-cadherin were selected as markers of proliferation (17), apoptosis (18) and epithelial-mesenchymal transition-associated migration (19), respectively. As presented in Fig. 4B, overexpression of ER $\beta$ suppressed the expression of PCNA and MMP-2, but promoted the expression of Bax, caspase-3 and E-cadherin in PC-3 and DU145 cells. These alterations in expression were reversed by treatment with PHTPP.

To further investigate the effects of ER $\beta$ on the progression of prostate cancer, ER $\beta$-targeting siRNAs were employed to downregulate ER $\beta$ expression in DU145 prostate cancer cells. The silencing effects of three siRNAs compared with a negative control scramble siRNA were reported via RT-qPCR analysis (Fig. 5A); siRNA-ER $\beta \# 1$ was selected for subsequent experiments, as it exhibited a notable effect on ER $\beta$ expression compared with siRNAs-ER $\beta \# 2$ and 3. Decreased levels of ER $\beta$ protein expression in prostate cancer cells following transfection with siRNA-ER $\beta \# 1$ were demonstrated via western blot analysis (Fig. 5B). ER $\beta$ knockdown induced similar effects to treatment with PHTPP; increased expression of p65 and $\mathrm{p}-\mathrm{I} \kappa \mathrm{B} \alpha$ was observed, but not of total I $\mathrm{I} \mathrm{B} \alpha$ compared with 

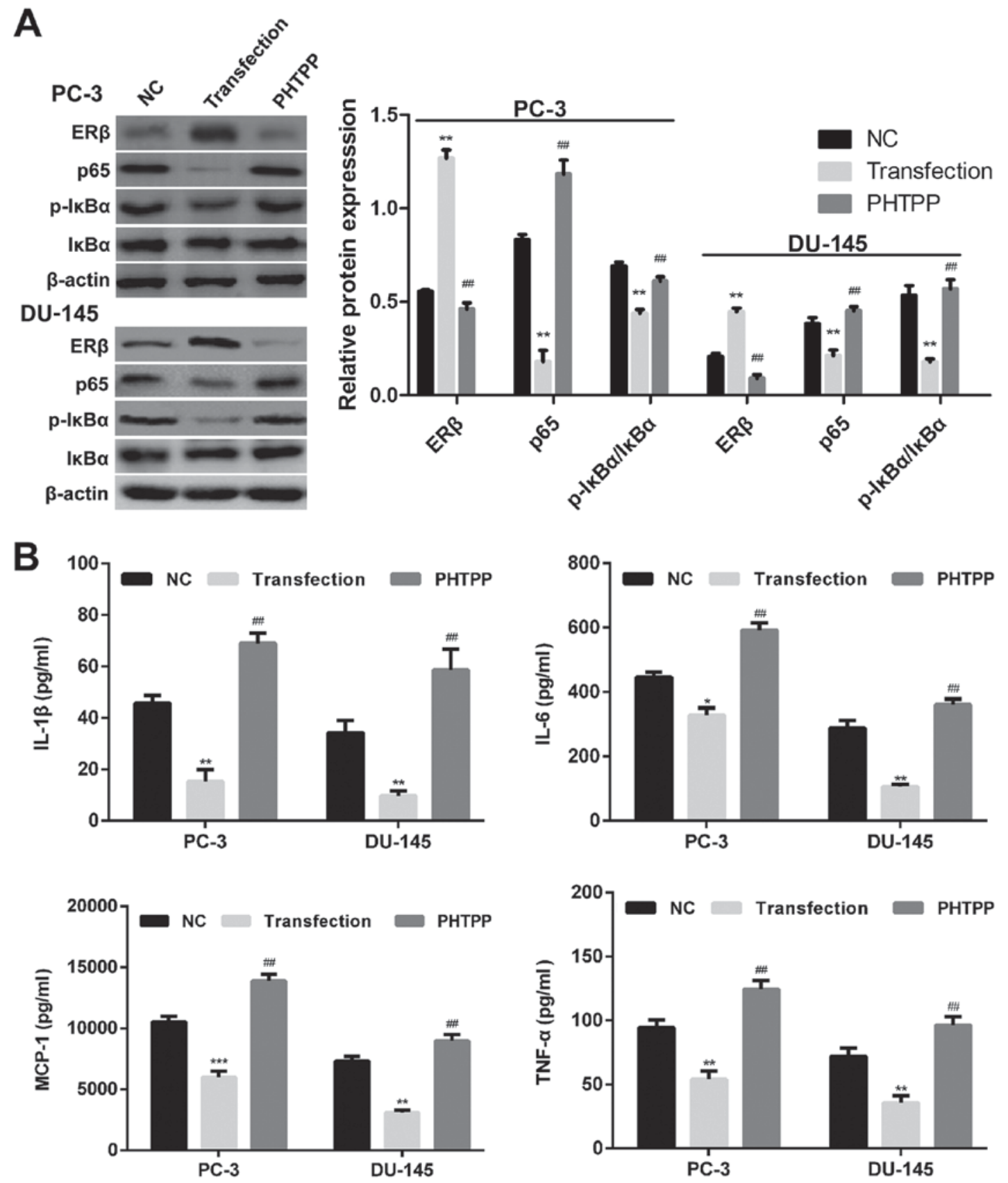

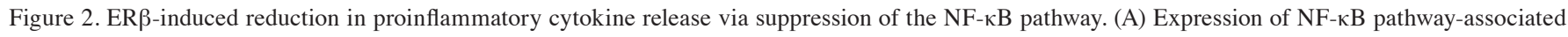
proteins in NC empty vector-transfected, ER $\beta$ expression vector-transfected and PHTPP-treated PC-3 and DU145 cells was determined via western blot analysis. (B) Production of inflammatory cytokines was determined using ELISA in NC, ER $\beta$-transfected and PHTPP-treated PC-3 and DU145 cells. Data are presented as the mean \pm standard deviation; ${ }^{*} \mathrm{P}<0.05,{ }^{* *} \mathrm{P}<0.01,{ }^{* * *} \mathrm{P}<0.001$ vs. $\mathrm{NC}$; ${ }^{\#} \mathrm{P}<0.05,{ }^{\# \#} \mathrm{P}<0.01$, vs. transfection group. ER $\beta$, estrogen receptor $\beta$;

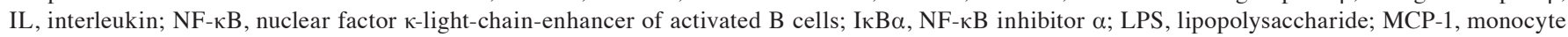
chemoattractant protein $1 \mathrm{p}$, phosphorylated; TNF- $\alpha$, tumor necrosis factor- $\alpha$.

scramble-transfected cells (Fig. 5B). Furthermore significantly increased cell viability (Fig. 5C), decreased number of apoptotic cells (Fig. 5D), upregulated expression of proinflammatory cytokines (Fig. 5E), enhanced cell migration (Fig. 5F) and altered expression of associated proteins (Fig. 5G) were reported in DU145 prostate cancer cells following transfection with siRNA-ER $\beta \# 1$ compared with scramble-transfected cells. Collectively, these findings indicated that upregulation of ER $\beta$ reduced the viability and migration, and increased the apoptosis of human prostate cancer cells, which may suppress the progression of prostate cancer.

\section{Discussion}

In the present study, it was revealed that ER $\beta$ overexpression reduced the inflammation induced by LPS treatment via regulating the levels of proinflammatory cytokines, including TNF- $\alpha$, MCP-1, IL-1 $\beta$ and IL-6. Furthermore, it was demonstrated that the ER $\beta$ antagonist PHTPP increased the expression of proinflammatory cytokines. Additionally, it was observed that ER $\beta$ overexpression suppressed the viability and migration of PC-3 and DU145 prostate cancer cells, and promoted apoptosis. These findings may improve 
A
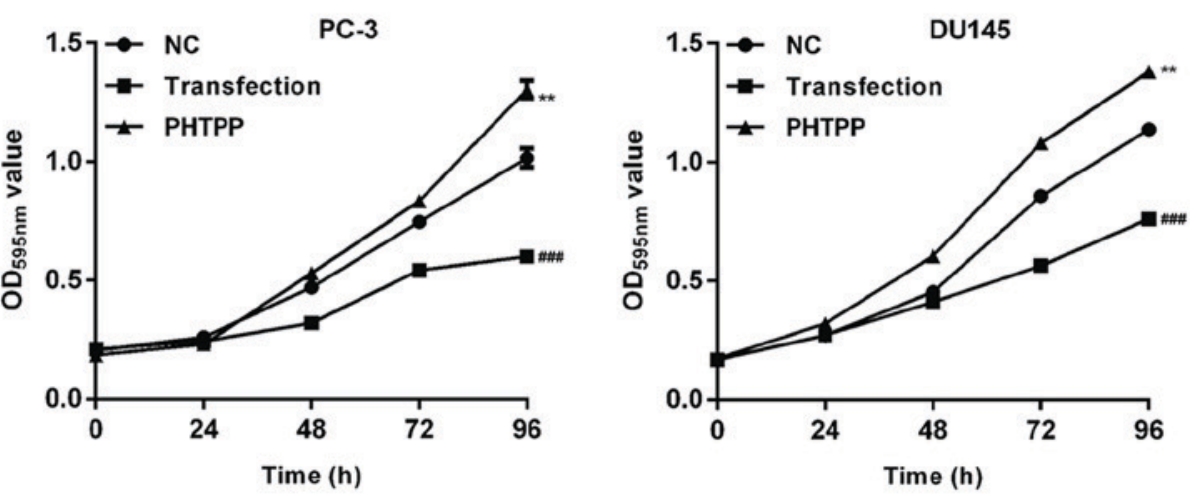

B
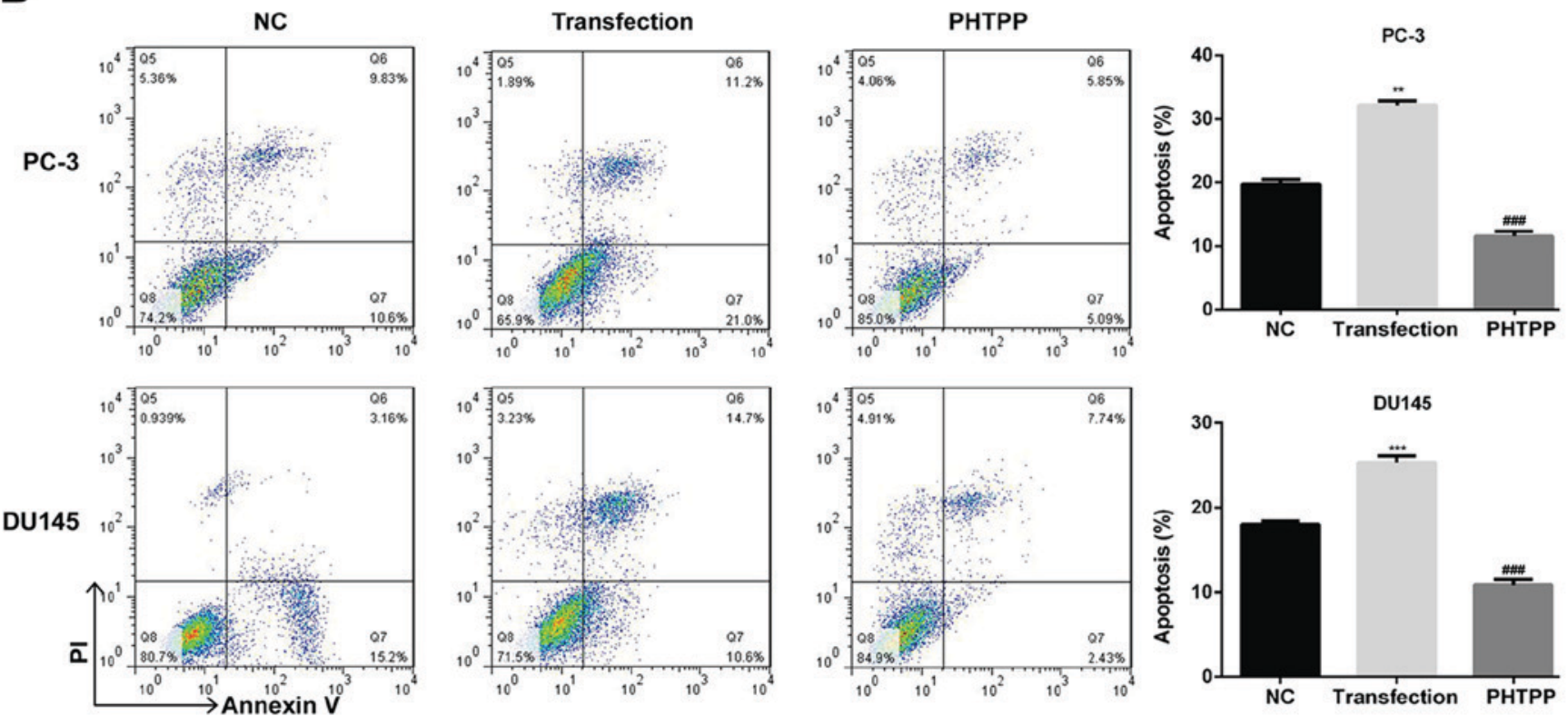

Figure 3. ER $\beta$ overexpression reduces the viability and promotes the apoptosis of prostate cancer cells. (A) Cell viability was investigated using an MTT assay in NC, ER $\beta$-transfected and PHTPP-treated PC-3 and DU145 cells. (B) Apoptosis was determined via an Annexin V/PI assay in NC, ER $\beta$-transfected and PHTPP-treated PC-3 and DU145 cells. Data are presented as the mean \pm standard deviation; ${ }^{* *} \mathrm{P}<0.01,{ }^{* * *} \mathrm{P}<0.001$ vs. NC; ${ }^{* \# \#} \mathrm{P}<0.001$, vs. transfection group. ER $\beta$, estrogen receptor $\beta$; NC, negative control; OD, optical density; PI, propidium iodide.

understanding of the possible mechanisms by which ER $\beta$, a tumor suppressor, may contribute to inhibition of the $\mathrm{NF}-\kappa \mathrm{B}$ pathway.

LPS is a common inducer of inflammation; exposure leads to the activation of a number of components involved in chronic inflammation processes, such as altered cytokine levels $(20,21)$. Carcinogenesis was studied in cells treated with LPS, as determined by tumor cell survival, proliferation, invasion and metastasis $(1,22,23)$. LPS induces PC-3 cell migration (24) by stimulating the production of TNF- $\alpha$ and IL-6 (25), and the serum levels of these cytokines are associated with stages of prostate cancer (26). A study investigated the effects of treatment in patients with localized aggressive periodontitis, and observed that improvement in clinical parameters correlated with reductions in responsiveness to LPS, as determined by the release of cytokines, including TNF- $\alpha$, IL-1 $\beta$, MCP-1 and IL-6 (27). In the present study, LPS-induced inflammatory responses were observed in PC-3 and DU145 prostate cancer cells, with elevated serum levels of TNF- $\alpha$, IL-1 $\beta$, IL-6 and MCP-1.

ER $\beta$ has been associated with the differentiation of prostatic epithelial cells, and was reported to exhibit antiproliferative effects on prostate cancer cells (28). The regulatory effects of estrogen on PC-3 cell proliferation are mediated by ER $\beta$, and can be inhibited by the ER $\beta$-selective antagonist PHTPP (29). The role of ER $\beta$ in oppressing androgen receptor signaling, and suppressing proliferation and inflammation, suggests that ER $\beta$ may be a potential therapeutic target to prevent the progression of prostate cancer (30). Differentiation of prostatic epithelial cells, in which ER $\beta$ serves a significant role, is a defensive mechanism required for the protection against inflammation in the prostate of FGF8b transgenic mice (31). The findings of the present study revealed that ER $\beta$ overexpression reduced the upregulated expression levels of TNF- $\alpha$, MCP-1, IL- 6 and IL-1 $\beta$ in PC- 3 cells induced by LPS, indicating a potential therapeutic role of ER $\beta$ in the reduction of inflammation in prostate cancer.

It was reported that, under physiological conditions, estrogen signaling via ER $\beta$ inhibited prostate gland growth $(32,33)$. Dihydrotestosterone inhibits prostate cancer cell migration and proliferation via conversion to $3 \beta$-Androstanediol, a metabolite that selectively interacts with $\operatorname{ER} \beta(34,35)$. It was previously demonstrated that treatment with four ligands of ER $\beta$ (tamoxifen, raloxifene, curcumin and genistein) inhibited 
A
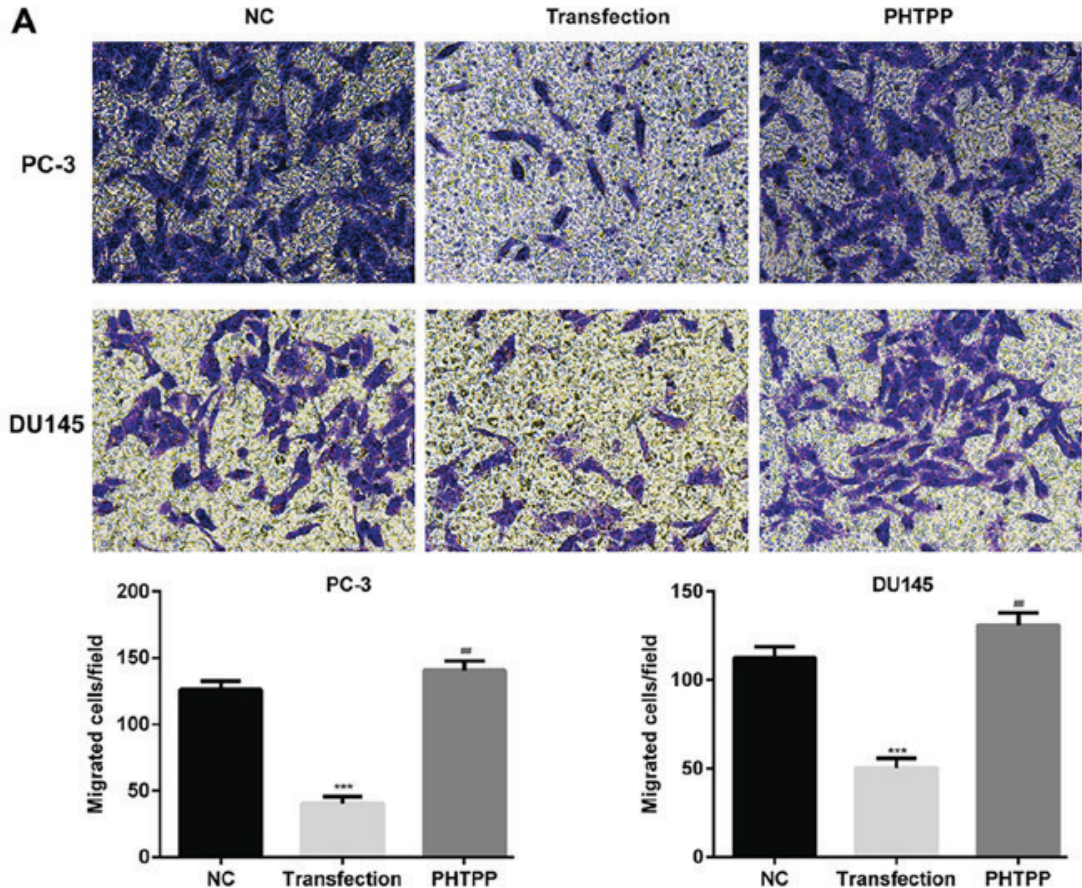

B
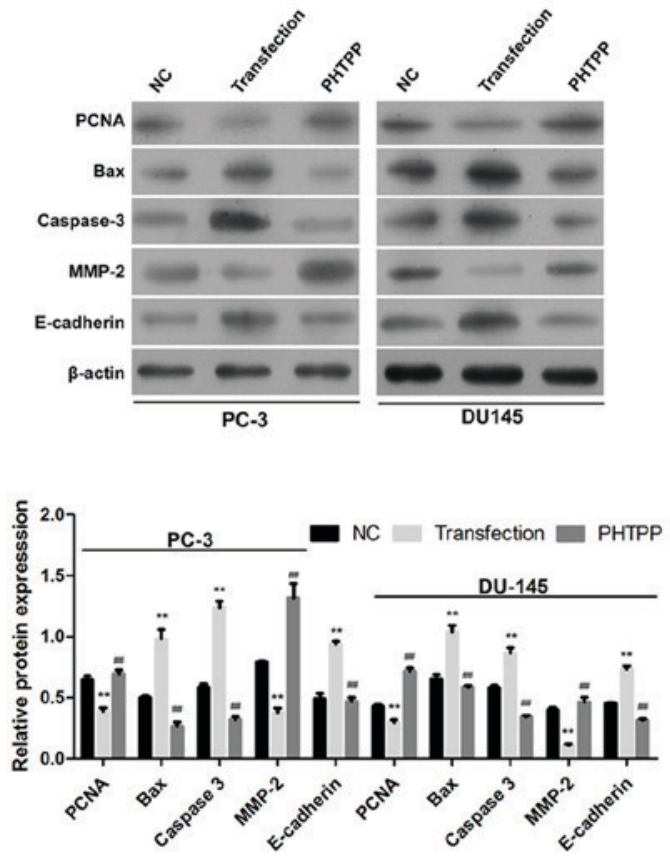

Figure 4. ER $\beta$ activation inhibits the migration of prostate cancer cells and alters the expression of proliferation-, apoptosis- and migration-associated proteins (A) Cell migration was determined using a Transwell assay in NC, ER $\beta$-transfected and PHTPP-treated transfected PC-3 and DU145 cells. (B) Expression of PCNA, Bax, caspase-3, MMP-2 and E-cadherin was evaluated via western blot analysis in NC, ER $\beta$-transfected and PHTPP-treated transfected PC-3 and DU145 cells. Data are presented as the mean \pm standard deviation; ${ }^{* *} \mathrm{P}<0.01,{ }^{* * *} \mathrm{P}<0.001$ vs. $\mathrm{NC} ;{ }^{\# \#} \mathrm{P}<0.01$, vs. transfection group. Bax, B-cell lymphoma 2 -associated $\mathrm{X}$ protein; ER $\beta$, estrogen receptor $\beta$; MMP-2, matrix metalloproteinase-2; NC, negative control; PCNA, proliferating cell nuclear antigen.

A

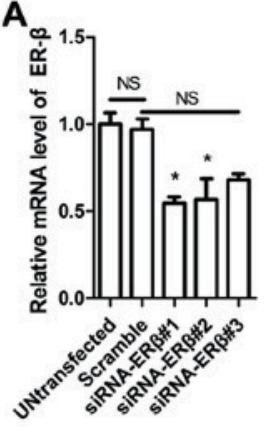

E

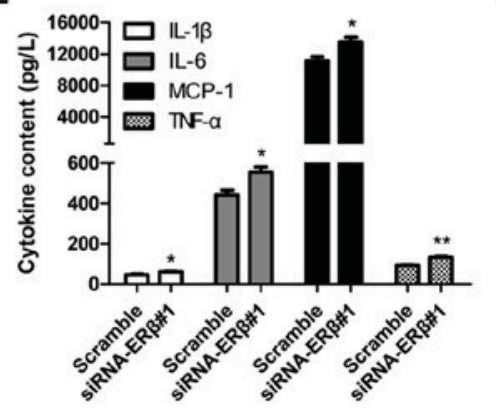

B

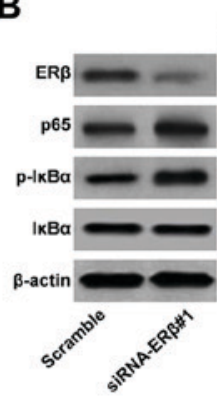

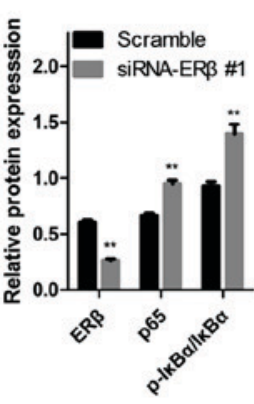

F

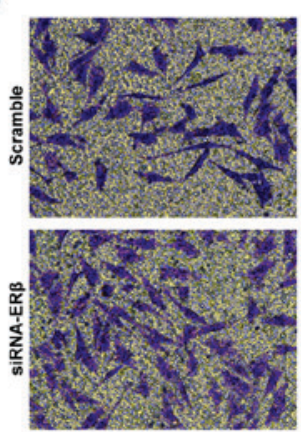

C

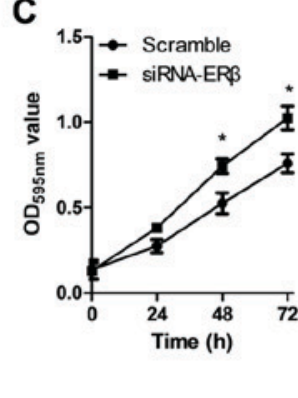

D
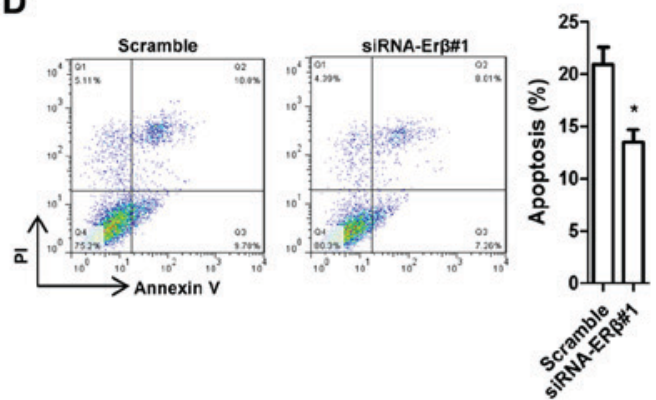

Figure 5. Effects of ER $\beta$-specific siRNA on inflammation, proliferation, apoptosis and migration of DU145 prostate cancer cells. (A) Expression levels of ER $\beta$ mRNA following treatment with siRNAs were determined via reverse transcription-quantitative polymerase chain reaction. (B) Expression of proteins associated with the nuclear factor $\kappa$-light-chain-enhancer of activated B cells pathway was determined via western blot analysis. (C) Cell viability of DU145 was measured with a MTT assay, with absorbance at $595 \mathrm{~nm}$ used as an index. (D) Cell apoptosis was determined via flow cytometry. (E) Secretion of proinflammatory cytokines was measured using ELISA. (F) Migration of DU145 cells was evaluated using a Transwell migration assay. (G) Expression levels of proliferation-, apoptosis- and migration-associated proteins in DU145 cells following transfection with siRNA-ER $\beta \# 1$ or Scramble were determined via western blot analysis. Data are presented as the mean \pm standard deviation; ${ }^{*} \mathrm{P}<0.05,{ }^{* *} \mathrm{P}<0.01$ vs. Scramble group. Bax, B-cell lymphoma 2 -associated X protein; cle, cleaved; ER $\beta$, estrogen receptor $\beta$; IL, interleukin; I $\mathrm{B} \alpha$, nuclear factor of $\kappa$ light polypeptide gene enhancer in B-cells inhibitor $\alpha$; MCP-1, monocyte chemoattractant protein 1; MMP-2, matrix metalloproteinase-2; NC, negative control; NS, not significant; OD, optical density; p, phosphorylated; PCNA, proliferating cell nuclear antigen; PI, propidium iodide; siRNA, short interfering RNA; TNF- $\alpha$, tumor necrosis factor- $\alpha$. 
prostate cancer cell proliferation and migration, suggesting a potential protective effect against the progression of prostate cancer (36). Consistent with these findings, it was observed in the present study that overexpression of ER $\beta$ reduced the viability and migration of PC-3 and DU145 cells, and promoted apoptosis.

$\mathrm{NF}-\kappa \mathrm{B}$ is activated by various signals via phosphorylation and degradation of the inhibitory $\mathrm{I} \kappa \mathrm{B} \alpha$ protein (37). NF- $\kappa \mathrm{B}$ functions via canonical and non-canonical pathways. A recent study proposed that $\mathrm{ER} \beta$ suppresses the activation of $\mathrm{NF}-\kappa \mathrm{B}$ activation, due to the negative correlation between $\operatorname{ER} \beta$ and p65 expression (14). In the present study, it was reported that the expression of $\mathrm{p} 65$ and $\mathrm{p}-\mathrm{I} \kappa \mathrm{B} \alpha$ was increased, and that of ER $\beta$ decreased in LPS-stimulated cells. Furthermore, ER $\beta$ overexpression reduced the expression of p65 and p-I $\mathrm{B} \alpha$, but not total I $\mathrm{B} \alpha \alpha$ expression; this effect was reversed by PHTPP. These findings suggested that the underlying mechanisms involved in the potential therapeutic effects of ER $\beta$ may be associated with suppressed $\mathrm{NF}-\kappa \mathrm{B}$ activation in prostate cancer cells.

In conclusion, the present study reported that activation of ER $\beta$ suppressed the NF- $\kappa$ B signaling pathway, and suggested that $\operatorname{ER} \beta$ may be a potential anti-inflammatory and anticancer agent in the treatment of prostate cancer.

\section{Acknowledgements}

Not applicable.

\section{Funding}

The present study was funded by the Internal Research Institutions Fund of Health and Technology Planning Commission of Yunnan Province (grant no. 2016NS209).

\section{Availability of data and materials}

All data generated or analyzed during this study are included in this manuscript.

\section{Authors' contributions}

LX and YL made substantial contributions to data acquisition and analysis, and were major contributors in drafting the manuscript. RT was responsible for interpretation of data; NZ conceived and designed the study, and revised the manuscript critically for important intellectual content. All authors have read and agreed with the final manuscript.

\section{Ethics approval and consent to participate}

Not applicable.

\section{Patient consent for publication}

Not applicable.

\section{Competing interests}

The authors declare that they have no competing interests.

\section{References}

1. Coussens LM and Werb Z: Inflammation and cancer. Nature 420 860-867, 2002

2. Winchester DA, Till C, Goodman PJ, Tangen CM, Santella RM, Johnson-Pais TL, Leach RJ, Xu J, Zheng SL, Thompson IM, et al: Variation in genes involved in the immune response and prostate cancer risk in the placebo arm of the Prostate Cancer Prevention Trial. Prostate 75: 1403-1418, 2015.

3. Sfanos KS, Isaacs WB and De Marzo AM: Infections and inflammation in prostate cancer. Am J Clin Exp Urol 1: 3-11, 2013.

4. Haverkamp J, Charbonneau B and Ratliff TL: Prostate inflammation and its potential impact on prostate cancer: A current review. J Cell Biochem 103: 1344-1353, 2008.

5. Kanda Y, Osaki M and Okada F: Chemopreventive strategies for inflammation-related carcinogenesis: Current status and future direction. Int J Mol Sci 18: E867, 2017.

6. McKown RL, Orle KA, Chen T and Craig NL: Sequence requirements of Escherichia coli attTn7, a specific site of transposon Tn7 insertion. J Bacteriol 170: 352-358, 1988.

7. Sun B and Karin M: The therapeutic value of targeting inflammation in gastrointestinal cancers. Trends Pharmacol Sci 35: 349-357, 2014

8. Nguyen DP, Li J, Yadav SS and Tewari AK: Recent insights into $\mathrm{NF}-\kappa \mathrm{B}$ signalling pathways and the link between inflammation and prostate cancer. BJU Int 114: 168-176, 2014.

9. Huang JJ, Chu HX, Jiang ZY, Zhang XJ, Sun HP and You QD: Recent advances in the structure-based and ligand-based design of IKK $\beta$ inhibitors as anti-inflammation and anti-cancer agents. Curr Med Chem 21: 3893-3917, 2014.

10. Gasparian AV, Yao YJ, Kowalczyk D, Lyakh LA, Karseladze A, Slaga TJ and Budunova IV: The role of IKK in constitutive activation of NF-kappaB transcription factor in prostate carcinoma cells. J Cell Sci 115: 141-151, 2002.

11. Verzella D, Fischietti M, Capece D, Vecchiotti D, Del Vecchio F, Cicciarelli G, Mastroiaco V, Tessitore A, Alesse E and Zazzeroni F: Targeting the NF- $\kappa \mathrm{B}$ pathway in prostate cancer: A promising therapeutic approach? Curr Drug Targets 17: 311-320, 2016.

12. Nakamura Y, Felizola SJ, Kurotaki Y, Fujishima F, McNamara KM, Suzuki T, Arai Y and Sasano H: Cyclin D1 (CCND1) expression is involved in estrogen receptor beta (ER $\beta)$ in human prostate cancer. Prostate 73: 590-595, 2013.

13. Wu WF, Tan XJ, Dai YB, Krishnan V, Warner M and Gustafsson JA: Targeting estrogen receptor $\beta$ in microglia and T cells to treat experimental autoimmune encephalomyelitis. Proc Natl Acad Sci USA 110: 3543-3548, 2013.

14. Mak P, Li J, Samanta S and Mercurio AM: ER $\beta$ regulation of $\mathrm{NF}-\kappa \mathrm{B}$ activation in prostate cancer is mediated by HIF-1. Oncotarget 6: 40247-40254, 2015.

15. Soshilov A and Denison MS: Role of the Per/Arnt/Sim domains in ligand-dependent transformation of the aryl hydrocarbon receptor. J Biol Chem 283: 32995-33005, 2008.

16. Livak KJ and Schmittgen TD: Analysis of relative gene expression data using real-time quantitative PCR and the 2(-Delta Delta C(T)) method. Methods 25: 402-408, 2001.

17. Zhao H, Lo YH, Ma L, Waltz SE, Gray JK, Hung MC and Wang SC: Targeting tyrosine phosphorylation of PCNA inhibits prostate cancer growth. Mol Cancer Ther 10: 29-36, 2011.

18. Shen H, Zeng G, Sun B, Cai X, Bi L, Tang G and Yang Y: A polysaccharide from Glycyrrhiza inflata Licorice inhibits proliferation of human oral cancer cells by inducing apoptosis via mitochondrial pathway. Tumour Biol 36: 4825-4831, 2015.

19. Wang S, Qiu M, Xia W, Xu Y, Mao Q, Wang J, Dong G, Xu L, Yang $X$ and Yin R: Glypican-5 suppresses epithelial-mesenchymal transition of the lung adenocarcinoma by competitively binding to Wnt3a. Oncotarget 7: 79736-79746, 2016.

20. Schetter AJ, Heegaard NH and Harris CC: Inflammation and cancer: Interweaving microRNA, free radical, cytokine and p53 pathways. Carcinogenesis 31: 37-49, 2010.

21. Xu P, Cai F, Liu X and Guo L: Sesamin inhibits lipopolysaccharide-induced proliferation and invasion through the p38-MAPK and NF- $\mathrm{KB}$ signaling pathways in prostate cancer cells. Oncol Rep 33: 3117-3123, 2015.

22. Mantovani A: Cancer: Inflammation by remote control. Nature 435: $752-753,2005$.

23. Hsu RY, Chan CH, Spicer JD, Rousseau MC, Giannias B, Rousseau S and Ferri LE: LPS-induced TLR4 signaling in human colorectal cancer cells increases beta1 integrin-mediated cell adhesion and liver metastasis. Cancer Res 71: 1989-1998, 2011. 
24. Li J, Chong T, Wang Z, Chen H, Li H, Cao J, Zhang P and Li H: A novel anticancer effect of resveratrol: Reversal of epithelialmesenchymal transition in prostate cancer cells. Mol Med Rep 10 1717-1724, 2014.

25. Im HJ, Park NH, Kwon YJ, Shin S, Kim D and Chun YJ: Bacterial lipopolysaccharides induce steroid sulfatase expression and cell migration through IL-6 pathway in human prostate cancer cells. Biomol Ther (Seoul) 20: 556-561, 2012.

26. Michalaki V, Syrigos K, Charles P and Waxman J: Serum levels of IL- 6 and TNF-alpha correlate with clinicopathological features and patient survival in patients with prostate cancer. $\mathrm{Br}$ J Cancer 90: 2312-2316, 2004.

27. Shaddox LM, Goncalves PF, Vovk A, Allin N, Huang H, Hou W, Aukhil I and Wallet SM: LPS-induced inflammatory response after therapy of aggressive periodontitis. J Dent Res 92: 702-708, 2013.

28. Christoforou P, Christopoulos PF and Koutsilieris M: The role of estrogen receptor beta in prostate cancer. Mol Med 20: 427-434, 2014.

29. Lombardi AP, Pisolato R, Vicente CM, Lazari MF, Lucas TF and Porto CS: Estrogen receptor beta (ER $\beta)$ mediates expression of $\beta$-catenin and proliferation in prostate cancer cell line PC-3. Mol Cell Endocrinol 430: 12-24, 2016.

30. Wu WF, Maneix L, Insunza J, Nalvarte I, Antonson P, Kere J, Yu NY, Tohonen V, Katayama S, Einarsdottir E, et al: Estrogen receptor $\beta$, a regulator of androgen receptor signaling in the mouse ventral prostate. Proc Natl Acad Sci USA 114: E3816-e3822, 2017.

31. Elo T, Yu L, Valve E, Mäkelä S and Härkönen P: Deficiency of ER $\beta$ and prostate tumorigenesis in FGF8b transgenic mice. Endocr Relat Cancer 21: 677-690, 2014.

32. Weihua Z, Lathe R, Warner M and Gustafsson JA: An endocrine pathway in the prostate, ERbeta, AR, 5alpha-androstane-3beta 17beta-diol, and CYP7B1, regulates prostate growth. Proc Natl Acad Sci USA 99: 13589-13594, 2002.
33. Prins GS and Korach KS: The role of estrogens and estrogen receptors in normal prostate growth and disease. Steroids 73 : 233-244, 2008

34. Dondi D, Piccolella M, Biserni A, Della Torre S, Ramachandran B, Locatelli A, Rusmini P, Sau D, Caruso D, Maggi A, et al: Estrogen receptor beta and the progression of prostate cancer: Role of 5alpha-androstane-3beta, 17beta-diol. Endocr Relat Cancer 17: 731-742, 2010.

35. Guerini V, Sau D, Scaccianoce E, Rusmini P, Ciana P, Maggi A Martini PG, Katzenellenbogen BS, Martini L, Motta M and Poletti A: The androgen derivative 5alpha-androstane-3beta, 17beta-diol inhibits prostate cancer cell migration through activation of the estrogen receptor beta subtype. Cancer Res 65: 5445-5453, 2005

36. Piccolella M, Crippa V, Messi E, Tetel MJ and Poletti A: Modulators of estrogen receptor inhibit proliferation and migration of prostate cancer cells. Pharmacol Res 79: 13-20, 2014.

37. Huong PT, Moon DO, Kim SO, Kim KE, Jeong SJ, Lee KW, Lee KS, Jang JH, Erikson RL, Ahn JS and Kim BY: Proteasome inhibitor-I enhances tunicamycin-induced chemosensitization of prostate cancer cells through regulation of NF- $\mathrm{NB}$ and $\mathrm{CHOP}$ expression. Cell Signal 23: 857-865, 2011.

(i) (9) This work is licensed under a Creative Commons Attribution-NonCommercial-NoDerivatives 4.0 International (CC BY-NC-ND 4.0) License. 